\title{
Didática dos Signos: ressonâncias na Educação Matemática contemporânea
}

\section{Didactics of Signs: resonances in contemporary Mathematics Education}

\author{
Lisete Regina Bampi ${ }^{*}$ \\ Gabriel Dummer Camargo ${ }^{* *}$
}

\begin{abstract}
Resumo
Neste artigo, problematizamos e analisamos o incentivo a atividades que envolvem a expressão do aprendizado de estudantes, refletindo mundos próprios que se manifestam em suas formas de aprender a matemática escolar, mesclando-se com seus modos de ser e pensar. Objetivando estabelecer conexões entre o "aprender" expresso por Deleuze e o "contemporâneo" por Agamben, queremos ver surgir um aprendizado genuíno no pensamento. Por meio de uma didática dos signos, observamos a natureza desses signos e suas possíveis conexões com a escola de Educação Básica. Sustentados no aprendizado de estudantes e professores, inquietados com o que é ensinado, vislumbramos um professor contemporâneo que pode revelar um ser artístico. Quem sabe, assim, possamos ampliar nossos horizontes e mostrar a produtividade da escola em sua riqueza de signos a decifrar.
\end{abstract}

Palavras chave: Didática. Professor. Educação Matemática. Aprender. Contemporâneo.

\begin{abstract}
In this paper, we problematize and analyze the incentive to activities that involve the expression of students' learning, reflecting their own worlds that manifest them selves in their forms of learning mathematics, blending with their ways of thinking and being. Seeking to establish connections between "learning", as expressed by Deleuze, and "contemporary", as expressed by Agamben, we wanted to seethe emergence of a genuine learning in thought. By means of a didactics of signs, we observed the nature of these signs and their possible connections with Elementary Education. Supported by the learning of students and teachers and concerned with what is being taught, we glimpse at a contemporary teacher that may reveal himself as an artistic being. Maybe then we may broaden our horizons and show the productivity of a school in its wealth of signs to be deciphered.
\end{abstract}

Keywords: Didactics. Teacher.Mathematics. Education.Learning. Contemporary.

\section{Nada mais do que a preparação ${ }^{* * *}$}

\footnotetext{
"Doutora em Educação pela Universidade Federal do Rio Grande Sul (UFRGS). Professora da Universidade Federal do Rio Grande do Sul, Faculdade de Educação, Departamento de Ensino e Currículo, Porto Alegre, Rio Grande do Sul, Brasil. Endereço para correspondência: Fernandes Vieira, 146/601, Bom Fim, Porto Alegre/RS, Cep: 90035-090. E-mail: lisete.bampi@ufrgs.br.

${ }^{* * *}$ Licenciado em Matemática pela Universidade Federal do Rio Grande do Sul (UFRGS). Cursa Bacharelado em Filosofia pela Universidade Federal do Rio Grande Sul (UFRGS).Professor da Escola Estadual de Ensino Médio André Leão Puente, Canoas/RS. Endereço para correspondência: Açucena 2999, Ap.304. Bl. 8, Igara, Canoas/RS, Cep: 92025840. E-mail: gabriel.dummer@ufrgs.br.

${ }^{* * * *}$ Este artigo tem por base a comunicação: "Sobre o que pode a escola - Do professor cansado ao professor contemporâneo" (Camargo; Bampi, 2014), apresentada no VII CIFE - VII Colóquio Internacional de Filosofia da Educação.
} 
Nada mais éramos do que a preparação, o invólucro, para o encontro dos passados que se dá por meio de nós, mas que faz parte de outra história, da história do depois: os encontros acontecem sempre antes e depois de nós, e nisso agem os elementos do novo que nos são barrados: o acaso, o risco, o improvável. (CALVINO, 2007, p. 215).

Há cenários que podem ser recriados na escola contemporânea, expressando experiências com o pensar e o aprender. As experiências estendem-se para além das formas de ensino-aprendizagem ${ }^{1}$, relacionando-se com sentidos outros que podem render mais cognitiva, social e culturalmente -, caso professores e estudantes disponham-se aos encontros com os signos do aprender. Com efeito, os signos deixam de ser somente intermediários entre não-saber e saber, podendo despertar o pensar (e não apenas estados da memória). Desde então, torna-se necessário ser sensível aos signos que o mundo emite (DELEUZE, 2003).

No contexto deste artigo, inclui-se a produtividade de uma docência artista com direito a pôr em cena aquilo que propiciou uma intensa preparação do professor (DELEUZE, 1997). Por sua vez, a matemática escolar surge como uma espécie de ferramenta do aprender, dominadora mundana de ações que buscam afirmar a potência da escola em suas realizações. O que se estabelece, então, manifesta-se na compreensão de que o conhecimento passa a funcionar de acordo com estas ou aquelas articulações, de acordo com este ou aquele uso que se possa dele fazer: são movimentos que almejam produzir algo singular, próprios às ressonâncias que vislumbramos, não são possíveis de antecipar em projetos de ensino, pesquisa ou extensão. Entretanto, eles podem acontecer no ato de executar uma ação: é o pensamento que surge como potência dos projetos em questão. À medida que enxergamos a imagem (produto do estilo artista), introduzimos algo de necessidade da descrição objetiva e da sugestão associativa (DELEUZE, 2003).

Numa educação que perfaz caminhos indizíveis, muitas vezes, deparamo-nos com a questão “o que pode a escola?”. A escola pode ensinar. Pode disciplinar. Pode organizar. Pode hierarquizar. Pode incluir e excluir saberes. A escola pode produzir um corpo docente envolto em seus muros, regras, projetos políticos pedagógicos, programas institucionais,

\footnotetext{
${ }^{1}$ As formas de aprendizagem, aparentemente, produzem vínculos entre aquele que ensina e o que o aprendiz aprende, ou seja, o aprendiz só pode aprender aquilo que é ensinado. Assim supomos poder controlar o aprendizado: conduzindo e conduzindo-nos a "pensar o já pensado" (GALLO, 2008, p.116). Interessa-nos, aqui, principalmente, uma relação com o paradoxo implícito que a "explicação" (RANCIÈRE, 2007) desenvolve: o da subdivisão ao infinito - sempre passado-futuro e jamais presente (DELEUZE, 2011, p. 78). Neste contexto, ela funciona como o hífen necessário às formas da expressão ensino-aprendizagem: uma espécie de ponte que pode ofuscar "o que acontece no meio" (CAMARGO; BAMPI, 2013).
} 
conhecimentos, tempos, espaços e planejamentos. A escola pode muito enquanto sustenta-se no igual e, ao mesmo tempo, ela nada pode, porque nada sabemos sobre ela: de que ela é capaz? $?^{2}$.

Talvez a questão “o que pode a escola?” deva ser formulada paralelamente à outra: "o que quer a escola?” ou, ainda melhor, “o que queremos da escola?”. Diante destas questões, como professores, enxergamo-nos intrigados com o que se "pode fazer" na escola. Parece-nos que esse "poder fazer" relaciona-se ao "como" responder as questões acima mencionadas, relaciona-se à invenção dos nossos próprios caminhos. Desde então, criamos uma hipótese simples e objetiva: a escola deve ensinar a aprender, "aprender a aprender", máxima que carrega em si mesma uma espécie de moral e um clichê a ser esgotado.

O aprender, assim, torna-se o foco do artigo. A pergunta “o que pode a escola?", por sua vez, afirma-se no aprendizado de estudantes e professores inquietados com o que é ensinado na escola contemporânea. Um aprendizado que não se sustenta somente na transmissão de dado conteúdo que será assimilado pelos estudantes, mas que se consolida nos mundos possíveis dos signos (DELEUZE, 2003). Nesses mundos pode se revelar um poder artístico daquele que ensina sobre aquele que aprende e, da mesma forma, daquele que aprende sobre aquilo que é apreendido. Os mundos dos signos mesclam-se com o aprender possível da escola. O que queremos, neste artigo, consiste em perceber esses signos. E, assim, instigados pelo clichê do "aprender a aprender", vislumbrar encontros que se manifestam em um aprendizado genuíno no pensamento.

$\mathrm{Na}$ segunda seção, por meio de uma didática dos signos, observamos que signos são esses e suas possíveis conexões com a escola de Educação Básica. Na terceira seção, exploramos possibilidades de encontros com os signos do aprender. Com Deleuze (2003), refletimos sobre como pode o professor sensível aos signos "esgotar" as possibilidades do “cansado" (DELEUZE, 2010), recriando brechas no "escuro" (AGAMBEN, 2013) que surge nas salas de aula contemporâneas. Na quarta seção, problematizamos o incentivo a atividades que envolvem a expressão dos estudantes, refletindo mundos próprios que se manifestam em suas formas de aprender matemática, mesclando-se com seus modos de ser e pensar. E, por fim, com Deleuze (2003; 2002) e Agamben (2009), vislumbramos um professor contemporâneo. Quem sabe, assim, poderemos mostrar a produtividade da Escola Básica em sua riqueza de signos a decifrar e, mais adiante, transmutar em alegria (SPINOZA, 2007).

\footnotetext{
${ }^{2}$ Aqui, traduzimos a declaração de Spinoza (2007): “não sabemos o que pode o corpo...”.
} 


\section{0 aprender e a didática}

Inspirados em Deleuze (2003), sustentamos que o aprender diz respeito, essencialmente, aos signos que se tornam "objeto de um aprendizado temporal, não de um saber abstrato" (DELEUZE, 2003, p. 4). Aprender torna-se (de início) em "considerar uma matéria, um objeto, um ser, como se emitissem signos a serem decifrados, traduzidos, interpretados. Não existe aprendiz que não seja egiptólogo de alguma coisa" (DELEUZE, 2003, p. 4). Todo o aprendizado remete aos encontros inusitados com signos que afetam o corpo, a mente e o pensamento. O ato de decifrar signos pode surgir no "recortar", "colorir", “colar" ou "digitalizar", por exemplo, constituindo-se no próprio aprendizado,

O primeiro mundo dos signos surge com a mundanidade: "não existe meio que emita e concentre tantos signos em espaços tão reduzidos e em tão grande velocidade" (DELEUZE, 2003, p. 5). O segundo mundo manifesta-se no amor, onde "o ser amado [...] exprime um mundo possível, desconhecido de nós. O amado implica, envolve, aprisiona um mundo que é preciso decifrar, isto é, interpretar" (DELEUZE, 2003, p.7). Seguindo, chegamos aos signos sensíveis que nos "proporcionam uma estranha alegria", conduzindo-nos pela necessidade de um trabalho do pensamento: busca do sentimento do signo (DELEUZE, 2003, p. 10-11). E, por fim, há os signos da arte, um mundo que "reage sobre todos os outros", visto que "todos os aprendizados pelas mais diversas vias, são aprendizados inconscientes da própria arte" (DELEUZE, 2003, p.13).

Os mundos dos signos são indissociáveis entre si: não há uma regra (ou uma seqüência) que permita defini-los, precisamente, no âmbito didático. No entanto, podemos buscar ilustrações, exemplos, onde os signos, de modo característico, "aparecem" numa sala de aula. Os signos mundanos, neste contexto, são os primeiros signos, os mais superficiais. No entanto, sem eles o aprender não se desenvolveria: o "aprendizado seria imperfeito e, até mesmo impossível, se não passasse por eles" (DELEUZE, 2003, p.6). Eles ganham o aspecto dos dados, das informações vazias em si mesmas, mas repletas em potências, contendo "uma perfeição ritual, como que um formalismo que não se encontrará em outro lugar" (DELEUZE, 2003, p.6).

As formas de ensino-aprendizagem podem ser pensadas como mundanidade, onde a memória possui um grande efeito. Os conteúdos dados, as fórmulas decoradas, os exemplos seguidos, as palavras do professor, muitas vezes, tornam-se signos mundanos em si mesmos: "matemática financeira", "geometria euclidiana", “poliedros", “múltiplos e primos” (BAMPI et al; 2013; 2014). Pois, tudo se torna mundano enquanto informação unidimensional. Uma 
reta não sai do plano, a não ser que façamos, por exemplo, um movimento ortogonal em relação ao mesmo. Neste caso, pode-se abrir um espaço de possibilidades, tornando possível algo antes impensado por um signo que parecia sem dimensão.

O amor torna-se sublime, por assim dizer, remete a um querer, a um deixar-se afetar pelo signo que convida ao decifrar: consiste em "procurar explicar, desenvolver esses mundos desconhecidos que permanecem envolvidos no amado" (DELEUZE, 2003, p.7). O signo amoroso não se deixa ver por completo, encontra-se envolvido na arte, seduzindo-nos enquanto que conduz nossos atos a serem decifrados. Provoca a vontade incontida de explorálos, de tê-los enquanto mundo próprio: “qual será minha parte do lucro?”, "ponto é..?”, "meu poliedro está bonito?”. Daí vem o ciúme, com seu perfume a ele inerente. O signo amoroso, muitas vezes, torna-se ilusório. Ao não se deixar mostrar, quando "abraçado", traz consigo formas que nem sequer imaginamos, mundos que não nos pertencem, instigando-nos a uma busca.

A decepção é uma das vestes mais desconfortáveis (e na moda) dos signos amorosos, trazendo o sofrimento de um aprofundamento, pode nos fazer desistir da nossa busca da verdade, ou aprendizado (DELEUZE, 2003): "acho que deveria ter mais lucro..."; "mas, plano não é bem isso...”; “esse poliedro não ficou tão legal assim...”, “deixa pra lá...”. Ora, no "abraço" do signo amoroso, já há signos sensíveis em ação: um sentir instigante que faz mover os signos em nós mesmos. Experimentá-los enquanto possibilidades de uma decifração que se revela, tateante perante nossos sentidos, pode nos aproximar do objeto, da obra de arte. Quando esses três mundos de signos reagem entre si, esgotando todas as suas possibilidades, a arte surge com a experiência singular de um aprender genuíno no pensamento.

No contexto deste aprender, enxergamos o professor na escola e o que ele pode, mediante as possibilidades do seu ensinar, perante a multiplicidade de signos a interpretar. Observando a matéria didática que nos envolve, o professor, num primeiro momento, poderia questionar-se sobre como extravasar os signos mundanos já existentes. E, então, possibilitar encontros com os signos amorosos, enquanto mundo seguinte do aprendizado. Podemos caracterizar, essencialmente, duas maneiras de possibilitar encontros com signos amorosos, ambos enquanto "apetite" pelo signo mundano a ser interpretado, ou melhor, na vontade pelo alimento oferecido. A primeira maneira surge na fome do corpo: necessidade de energia mediante um cansaço de atividades repetitivas, mesmo que diferentes. A segunda, e nem sempre eficiente, surge nos sentidos, naquilo que se manifesta no gosto. É bonito? É cheiroso? É apetitoso? É provocante? Ora, o “apetite nada mais é que o esforço pelo qual cada 
coisa encoraja-se a perseverar no seu ser, cada corpo na extensão, cada alma ou cada ideia no pensamento (conatus)"33 (DELEUZE, 2002, p. 27).

Qual é o alimento oferecido nas salas de aula? Conteúdos, exercícios, exemplos, explicações, ilustrações. Há mais. E, também, há menos. E, também, há muito. O muito pode tornar-se pesado, até cansar. E o apetite? Onde estará? Como despertá-lo? As afecções são necessárias à consciência do conatus (SPINOZA, 2007). Podemos realizar, por uma associação intempestiva, uma relação análoga, onde os signos amorosos surgem como causa da consciência dos signos mundanos. Enquanto mundanos, os signos que remetem dos dados, surgem como substitutos de uma ação (ou pensamento), ocupando-lhe o lugar, pretendendo valer por seu sentido: "não se pensa, não se age, mas emitem-se signos” (DELEUZE, 2003, p.6).

Assim, só adquirimos a consciência dos dados, da informação por meio de uma motivação amorosa, seja ela intrínseca ou extrínseca, testemunhando a variação do conatus em função dos corpos ou das outras ideias. E, nesta experiência, a consciência mostra-se, naturalmente, no lugar de uma ilusão, caracterizando-se nos signos amorosos em que tentamos capturar, pela própria consciência, o objeto amado, iludindo-nos em ciúmes de mundos que não nos pertencem. As afecções remetem às paixões de alegria e tristeza: alegria dos signos materiais do mundo sensível; tristeza do ciúme que os signos amorosos trazem ao esconder o objeto amado e, também, na decepção de interpretá-lo objetivamente (DELEUZE, 2003, p.34).

A ordem das causas, e dos encontros, é uma ordem de composição e decomposição de relações que afetam infinitamente toda a natureza. Composição e decomposição, respectivamente, são as possibilidades de saciar o apetite: possibilitar encontros com os signos ou deixá-los que se desvaneçam e sejam substituídos por outros signos mundanos. No sentido de possibilitar que os encontros com os signos desenvolvam-se numa sala de aula, como professores, podemos nos apresentar, essencialmente, de três formas: sendo tiranos (lei do tirano), libertadores (lei de Moisés) ou salvadores (lei de Abraão ou de Cristo).

No contexto desta associação, alguém poderia estabelecer um sentido pretensioso. Contudo, o que estabelecemos são simples conexões de conceitos que podemos utilizar como professores de um aprendizado que, em si mesmo, já é imoral (KOHAN, 2009). Afinal, se não entendemos a regra de três, nós a consideramos um dever, podemos aplicá-la em um

\footnotetext{
${ }^{3} \mathrm{O}$ conatus, assim como suas diversas determinações (ou afetos), é, também, na alma, "modos de pensar" que temos consciência na medida em que as ideias de afecções o determinam precisamente: "eis porque Spinoza define o desejo como o conatus tornado consciente, sendo a afeç̧ão a causa dessa consciência" (DELEUZE, 2002, p.66).
} 
exercício. Eis uma das funções dos signos mundanos: uma moralização do aprender. A possibilidade de que a associação seja indispensável à moral do aprendizado, por sua vez, possui três modos de ação sobre o conhecimento:

\begin{abstract}
A lei, moral ou social, não nos traz conhecimento algum, não dá nada a conhecer. $\mathrm{Na}$ pior das hipóteses, impede a formação do conhecimento (a lei do tirano). Na melhor, prepara o conhecimento e o torna possível (a lei de Abraão ou de Cristo). Entre esses dois extremos, a lei supre o conhecimento naqueles que são incapazes de obtê-lo em função do seu modo de existência (a lei de Moisés) (DELEUZE, 2002, p. $30)$.
\end{abstract}

De qualquer modo, o professor tirano, o professor Moisés e o professor Abraão estão, intimamente, vinculados como professores em experiências singulares de tempos distintos, sendo exigidos de acordo com a necessidade de cada época. Não há chrónos que os antecipe. Contudo, no kairós podemos enxergar um portal celeste que possibilita o encontro dos três tempos num aión do aprender (KOHAN, 2004). No entanto, como encontrar as possibilidades de tais encontros com os signos do aprender? Como professores, qual deles é o bom ou mau? Há diferenças qualitativas dos modos de existência bom/mau. Não sabemos ao certo. Porém, o que podemos enquanto professores de matemática?

\title{
30 professor cansado e esgotado
}

Podemos considerar como o bom professor aquele que aumenta potências, possibilitando encontros com os signos do aprender. Por outro lado, o mau professor seria aquele que deixa os encontros ao acaso, impotente para explorá-los em algo outro, apenas reage a eles. No entanto, já antecipamos que não há professor bom ou mau. Acreditamos na potência de professores que se deixam afetar (mais ou menos) pelos signos do aprender ou que possuem (mais ou menos) uma sensibilidade aos encontros que podem dar a conhecer potências em uma sala de aula.

A noção de "cansado" (DELEUZE, 2010) que problematizamos não se fecha sobre si mesma, ao contrário, cerca-se de possibilidades. As possibilidades conflagram-se em recognições múltiplas necessárias ao aprender-acontecimento. Os atos recognitivos existem e ocupam grande parte da nossa vida mundana: é um poliedro, é uma função linear, é um bloco lógico. Todos somos professores cansados. Ensinamos conteúdos, ministramos aulas, delimitamos didáticas, produzimos dados: a repetição faz parte de nossos afazeres. Há igual por todo lado. O cansado continua a ensinar e, muito bem, por vezes. No entanto, o almejado novo, e diferente, parece não se apresentar ao professor cansado. E o professor cansado torna-se um tirano e, por vezes, um Moisés. 
O professor esgotado já foi e está cansado. Contudo, esgotou o possível. Ele está em atividade, cansado de alguma coisa e esgotado de nada. Esgota o que não se realiza no possível. Ele acaba com o igual para além de todo o cansaço. Não vê apenas o igual em suas aulas, em suas didáticas, em suas explicações, está sensível aos signos do aprender. Sua fome não é apenas dos sentidos. Mas, também, do cansaço que o esgotou e devora o impossível pelas beiradas mundanas, inclusive (DELEUZE, 2003; 2010). O cansado realiza o possível em função de objetivos necessários ao cansaço (inerentes a projetos políticos pedagógicos ou a preferências didáticas e metodológicas), por exemplo: confecciono sólidos geométricos de cartolina para ensinar noções básicas de geometria.

Além disso, o cansado tenta abocanhar o meio naquilo que escapa pelas brechas mundanas que possibilitam encontros com hieróglifos necessários ao aprender. Aqui, a repetição pode tornar-se diferença. O velho pode manifestar-se no novo. O cansado pode surgir enquanto esgotado. E, assim, sucessivamente, as combinações se perfazem além do possível, tornando-se experiências singulares de um aprender artístico que pode se revelar. Porém, o que podem aqueles que abrem os caminhos do aprender? Há um cenário a ser desbravado na escola contemporânea que não consiste em um simples cenário.

O ambiente, o tempo, os estudantes, as merendeiras, as sinetas, os alarmes, as didáticas, os recursos, os conhecimentos (a lista é infindável) estão ao nosso redor. Os professores têm que juntar tudo isso como se estivessem enchendo uma panela de ensino, muitas vezes, de pressão. Nesta cena, o aprender torna-se um alimento que exige preparação: "horas e horas de trabalho e, antes ainda, uma longa série de experiências e aperfeiçoamentos" (CALVINO, 1995, p. 34). Ele possui um gosto diferente para cada um que o experimenta; um sabor que só pode ser sentido quando se tranca em si mesmo, "mimetizando-se no percurso interior de suas sensações" e no desejo de comunicar o que se sente (CALVINO, 1995, p. 37).

Os professores já sabem de tudo isso? Já trabalham com isso tudo! Talvez por trabalharem sempre com isso, cansados, sem energia, podem estagnar diferenças possíveis. Afinal, o que pode, pode o possível. E o que nem sequer sabemos? Impõe-se. Quando esgotamos o possível, podemos mais. E o mais se torna diferente. Podemos encontrar o mais no menos, o diferente no igual. O novo está, também, no velho. O arcaico renova-se na sensibilidade de professores e estudantes que se deixam envolver em brincadeiras, por 
exemplo, com um "chapéu imprevisto"4. E, sobretudo, renova-se em potências: aqui, sujeitamo-nos em atos.

Os dados mundanos não surgem apenas como memórias ou vacuidades informativas. Neles, há encontros amorosos e sensíveis. Da mesma forma, também, há mundanidade na arte. O espaço e o tempo surgem como dados, extensões do chrónos (KOHAN, 2004), onde os professores moldam-se em didáticas diversas, observando as brechas por onde a arte escapará e integrará a si mesma enquanto forma.

De forma semelhante ao tempo de Heráclito que brinca como uma criança, a memória do poeta brinca irreverente com o passado, o presente e o futuro: altera sua ordem, não respeita sua sucessão; abre, a cada vez, um novo início da não continuidade, do não progresso, da não evolução. A memória se faz companheira e amiga da invenção, de um novo tempo, de um novo pensar (KOHAN, 2004, p.4).

Aproveitar os encontros não é fácil. Torna-se possível. Algo que o professor pode. O estudante pode. A escola pode, até mesmo, de acordo com um conteúdo a ser cumprido. Preso no tempo, um pensar pode estar lá, mesmo no menos, ou nos velhos moldes já existentes. O diferente não se manifesta, necessariamente, no novo que, por sua vez, não surge, necessariamente, como diferente. A arte de ensinar, além da didática instituída (e com ela) remete a um aprender em movimento como imagens de possibilidades que não existem. E, por não existirem, por serem impossíveis, é que aprendemos e ansiamos por elas. É o aprender almejado que surge? Sobretudo, o aprender que se manifesta com a obra de arte. Assim, o pensado, na sua singularidade, torna-se diferente. E, o mesmo, ainda assim, é outro. Ele surge enquanto potência, manifestando-se em metodologias, planejamentos, avaliações e matérias afins na sala de aula e na escola.

Muitas vezes, para alcançar o diferente, queremos fugir das explicações, dos exercícios, dos exemplos, não de modo a livrarmo-nos deles. Pois, estão sempre no nosso encalço, as mundanidades são muito rápidas. Contudo, oportunizam possibilidades de aprender decorando, amando, sentindo, ensaiando e, enfim, artistando em educação (CORAZZA, 2007). O que pode a escola (e o que pode o professor) na potência da escola como ambiente, como instituição, como forma, como espaço, como tempo, como mundo? Apostamos que se manifesta em render-se ao convite que os encontros com os signos do aprender proporcionam, por exemplo, através das didáticas que recriamos, de um exercício que aplicamos, da falta de tempo e de espaço, ou mesmo, de uma pergunta ou questão, de uma fórmula ou de um raciocínio, de um olhar ou de um aperto de mão. Sustentamos que criar,

\footnotetext{
${ }^{4}$ Trata-se de uma atividade sobre o ensino de múltiplos e primos, realizada com estudantes da Educação Básica, onde recolhemos algo que a transcendeu, infiltrando-se pelas membranas do tempo e espaço do ensinar (BAMPI et al, 2014).
} 
também, surge como recriar com o que temos nas mãos, reinventando-o, abrindo caminhos. E isso sempre se faz. Nada é igual. E somente isso.

Seguem algumas possibilidades no âmbito de um cenário que produzimos como efeitos de ressonâncias entre experiências que almejam ser criadas. Desde então, um ser artístico poderá surgir: o professor e o estudante podem tornar-se naqueles que extrairão das condições arcaicas de que dispomos uma imagem preciosa que se reencarnará nas suas condições artísticas (DELEUZE, 2003; AGAMBEN, 2013).

\section{Ressonâncias entre}

Em nossas experiências com a docência, muitas questões pairam ao redor da vontade de tornar mais efetivo o ensino da matemática. Buscamos alternativas para as nossas aulas, objetivando com que os alunos aprendam e, não menos importante, que percebam esse aprender. E, também, o nosso, na medida em que nos dispomos a fazer com alguém. Tomamos o espaço das salas de aula em sua multiplicidade, buscando por uma Educação Matemática voltada a sensibilizar os estudantes na expressão de seu próprio aprender. Dialogamos com as palavras e os saberes das experiências entre disciplinas que constituem espaços de formação (BAMPI; MOELLWALD; CAMARGO, 2015). Sustentados no aprender expresso por Deleuze (2003), recriamos cenas da educação, narrando, discutindo, problematizando, inventando, tecendo sentidos para o que emerge na escola contemporânea ${ }^{5}$.

Para expressar o nosso cenário, uma sensibilidade à espreita pode ser uma possibilidade para dar vivacidade ao que nos acontece com as experiências nas escolas e na universidade. Tomamos como matéria o que surge em nossos escritos, tais como: publicações anteriores, relacionadas aos estágios de docência em matemática, passando pelo PIBID Programa Institucional de Bolsa de Iniciação à Docência. Seguindo entre ressonâncias de projetos: um de pesquisa sobre o aprender em Deleuze (2003); outros de Ensino da Ciência, desenvolvidos em uma escola da rede pública na cidade de Canoas/RS, encontros com signos ressoaram nas experiências que traduzimos.

Os signos são múltiplos e, muitas vezes, intraduzíveis para as palavras que ressoam através dos lábios, ouvidos e dedos que vibram entre canetas e teclados. Com Deleuze (2003), deixamos hieróglifos a serem decifrados nas cenas que recriamos com a matéria que

\footnotetext{
${ }^{5}$ Nesta seção, utilizamos itálico para expressar falas, comentários, gestos, sons, imagens: signos didáticos que traduzimos, a partir de registros em nossos diários, durante a realização de atividades desenvolvidas em uma escola da rede pública entre os anos 2013 e 2015.
} 
coletamos. O que está em questão é certa disposição de escrever, ensinar e aprender, reinventando-nos na experiência e no pensar. Convidamos nossos leitores a aceitar o convite de integrar-se ao nosso mundo-cenário, escrito num tempo chrónos. Porém, ele expressa o nosso aprendizado, dissipando-se em nossas palavras e experiências que levaram estudantes e professores a deixar-se envolver pelo imprevisto na escola contemporânea.

Cenário I. A vontade de ensinar o respectivo conteúdo, com todas as suas nuances, e dados, exemplos e exercícios, mescla-se no "como fazer" do professor enquanto regente de um aprender ainda, inoperante, ou melhor, invisível no tempo chrónos. A matemática financeira deve ser dada: conteúdo necessário, podendo ser pensado como dado mundano que se estabelece em proporções, juros, descontos, investimentos. No entanto, com a matemática financeira, os estudantes enquanto sujeitos escolarizados necessitam desvendar uma dada questão, estabelecer metas, alcançar lucros ou dividir despesas. Questão que (em seus tons cambiáveis)se manifesta em proporções, em divisões que, por sua vez, devem satisfazer aos envolvidos com ela.

\section{- A empresa deu certo! Tivemos lucro. Isso é bom.}

E quanto cada sócio deve ganhar, sabendo que cada indivíduo investiu um valor diferente dos demais? Ora, como fazer uma divisão justa de um lucro obtido? Este foi o tema de uma oficina realizada com alunos do Ensino Médio de uma escola pública. E as respostas obtidas foram aceitáveis dentro de cada grupo de sócios formado com os estudantes. Muitos dos grupos, independente do investimento de cada indivíduo, decidiram que o melhor seria dividir os lucros da empresa fictícia, igualmente, entre eles.

- E isso está certo?

A forma proporcional é que deveria ser a correta. Sim, deveria, mas, para muitos, não foi.

- E onde está o erro?

A divisão justa foi realizada, explicada e aceita pelas partes interessadas. Surgiram outras formas de divisão "justa" entre os alunos, inclusive a proporcional que, também, estava lá enquanto possibilidade. $O$ que observamos foi um aprender manifestado num desenvolvimento artístico? Talvez inventor (KOHAN, 2013)? As respostas da questão foram estabelecidas segundo as próprias visões de mundo dos estudantes. Matematicamente corretas?

Cenário II. Questões simples e difíceis.

-O que é ponto?

- O que é reta? 
— O que é plano?

Dados da geometria euclidiana? Podemos pensá-los como informações mundanas enquanto conteúdo a ser ensinado nas mais diversas situações de sala de aula. E essas noções geométricas? Quem será capaz de explicá-las? Parecem tão obscuras. Os estudantes devem tentar. Como responder as questões?

—“Ponto é ponto!", diz um deles.

— "Reta é reta!", afirma outro.

— "Pois, eu tenho um plano mirabolante!", complementa um terceiro.

As respostas parecem fáceis. No entanto, fogem da linguagem e da escrita. Há tropeços nas tentativas, comparações nas distinções.

— Ponto final da frase... Menor distância entre dois pontos... A mesa, o chão...

Como explicar o que são as noções de ponto, reta e plano? É difícil.

- Não consigo ver uma resposta.

Mesmo assim, a explicação é realizada.

- É só mostrar ...

Mas, também, é necessário escrever, o signo mundano deve aparecer para que, então, possamos aprisioná-lo em nossos enquadramentos. No entanto, ele continua a fugir.

- Está na ponta da língua!

Alguns estudantes desenham, sentem, tocam a folha com dedo indicador, espalmam a mão sobre a mesa, fazem gestos ligando dois pontos invisíveis no ar.

- Ponto é uma localização...

- A menor distância entre dois pontos numa superfície esférica não é uma reta?

- A reta é infinita, com infinitos pontos... O plano é infinito, com infinitas retas...

- O que tem mais pontos: uma reta ou uma circunferência?

— Duas retas paralelas podem se encontrar?

- Onde? E depois?

A revelação sobre o tipo de questão com a qual estavam trabalhando e, quem sabe, pensando deixou muitos estudantes de olhos perplexos, suspirando de indignação.

- Não há definição para esses conceitos.

Sim, ponto, reta e plano são chamados de noções primitivas da geometria euclidiana, não possuindo, portanto, uma definição específica. Antes são concebidos pela intuição, segundo princípios vagos, como "ponto é aquilo de que nada é parte" (EUCLIDES, 2009, p.97). O signo mundano parece que escapou por entre nossos dedos. No entanto, sentimos seu peso, perseguimos palavras inexistentes, a fim de desvendar o que estava encoberto: hieróglifos indecifráveis. Usamos estratégias afins, gestos afins, signos afins foram emitidos. 
Será que cada um aprendeu em si mesmo o que é ponto, reta e plano? E, também, geodésica, localização, coordenada, infinito, geometria esférica, geometria projetiva? Quem sabe.

Cenário III. Agora, vamos construir poliedros feitos de cartolina. Primeiro, sorteamos quais poliedros deveriam ser confeccionados pelos grupos de alunos. Depois,os alunos medem, desenham, recortam, dobram, encaixam e colam. Neste meio, há algo que escapa do conteúdo, do dado, do conhecimento matemático necessário para produzir um poliedro do saber que possibilita defini-los (ou não). Aqui há uma brecha? Produzir. São eles que estão produzindo. Os poliedros lhes pertencem (e a mais ninguém). Os sólidos geométricos são obras de suas medições, de seus desenhos, de seus recortes, de suas dobraduras, de seus encaixes e de suas colagens.

Assim, nesta produção, os alunos envolvem-se em deixar os poliedros com suas próprias marcas, com sua própria arte e, alguns, literalmente, com suas digitais registradas. O olho, ainda roxo, de um aluno que se envolveu numa briga, alguns dias antes da realização da atividade, tornou-se registro nas faces do poliedro que seu grupo produziu. Por sua vez, o poliedro "digital" ficou com pouco espaço para suportar tantas marcas de dedos em tantas cores distintas. Outro poliedro ficou marcado com letras de músicas em língua inglesa e de desenhos como tatuagens tribais. Sim, não havia como negar que aqueles poliedros lhes pertenciam. Suas próprias obras de arte? Arte refletida de suas próprias vidas contemporâneas.

\section{O professor contemporâneo}

O que podemos para tanto? O que pode um corpo? Não sabemos o que pode um corpo, de que ele é capaz (SPINOZA, 2007): "porque não o sabemos, tagarelamos" (DELEUZE, 2002, p.24). No contexto deste artigo, tagarelar pode ser pensado como explicar ou, mesmo, achar que a palavra pode exprimir toda a potência do corpo. A explicação é parte, potência do corpo, mas é só mais um dos mil meios de movê-lo. Da mesma forma, os signos do aprender possuem muitas outras potências, além da ação da explicação, dos exercícios, dos exemplos (são infinitas enquanto atributos). Talvez uma noção de paralelismo (SPINOZA, 2007) possa expressar esta equivalência dos signos enquanto corpo do aprender, a explicação e as didáticas, como um todo, podem manifestar-se enquanto alma. Os signos que movem o corpo podem surgir enquanto o corpo em si, um não é superior ao outro. A ação não remete a ação no outro. 
É, pois, por um único e mesmo movimento que chegaremos, se for possível, a captar a potência do corpo, para além das condições dadas do nosso conhecimento, e a captar a força do espírito, para além das condições dadas da nossa consciência. Procuramos adquirir um conhecimento das potências do corpo para descobrir paralelamente as potências do espírito que escapam à consciência, e poder comparálos (DELEUZE, 2002, p.24).

$\mathrm{Na}$ consciência, recolhemos apenas os efeitos dessas composições e decomposições: alegria na composição e tristeza na decomposição (ameaçando a nossa coerência). Daí o ciúme, a decepção. Enquanto professores cansados, recolhemos apenas o que acontece, o efeito dos corpos sobre nós. Esse efeito na forma de emoções, ou mesmo da memória, não surge necessariamente como um aprender. As condições em que conhecemos, e tomamos consciência, levam-nos apenas a ter ideias inadequadas - confusas e mutiladas -, efeitos distintos de suas próprias causas. O bom existe quando um corpo compõe, diretamente, a sua relação com o nosso e com sua potência que aumenta a nossa. O mau decompõe a nossa essência enquanto potência de ação.

Bom é aquele que se esforça, tanto quanto pode, por organizar os encontros, por se
unir ao que convém à sua natureza, por compor a sua relação com relações
combináveis e, por esse meio, aumentar a sua potência. Mau, ou escravo, ou fraco,
ou insensato, aqueles que vivem ao acaso dos encontros, que se contentam em sofrer
as consequências, pronto a gemer e a acusar toda vez que o efeito sofrido se mostra
contrário e lhe revela a sua própria impotência (DELEUZE, 2002, p. 29).

Mas, como transmutar as afecções através de ações em que as paixões, estabelecidas em alegria e tristeza, sejam possibilitadas pelos signos amorosos enquanto mundos de um aprender possível? Aqui, deslumbramos um dos problemas da Ética (SPINOZA, 2007): como alcançar paixões alegres e transmutá-las em sentimentos livres ativos? Se o caminho que conduz a eles parece muito difícil de ser trilhado, ele pode, entretanto, ser vislumbrado na experiência que se traduz na decifração de signos, remetendo-se uns aos outros na busca da verdade. Quem busca a verdade na escola contemporânea? Aquele que tem necessidade daquilo que nos faz aprender, ou seja, é a experiência concreta que nos leva à busca. Não devemos estranhar que nossos artistas façam falar seus corpos. Suas formas de expressão, seus mundos, suas atitudes artistas, muitas vezes, parecem-se com as dos sonhos, formando uma espécie de alfabeto matemático para os iniciados.

Quanto mais difícil for a conquista dessa "outra experiência", tanto mais se encontrará sinais por toda a parte no caminho do aprendizado, se "nós permanecermos jovens" (BENJAMIN, 2009, p.24). O aprender enquanto inteligência não é instantâneo, só chega depois: é contemporâneo. Ao observarmos a noção de "contemporâneo" (AGAMBEN, 2009), talvez possamos ampliar nossos horizontes na busca da verdade. Como seria, então, um 
professor contemporâneo? Ora, "contemporâneo é aquele que mantém fixo o olhar no seu tempo, para nele perceber não as luzes, mas o escuro" (AGAMBEN, 2009, p.62).

O professor cansado, como já mencionado, apenas reage aos efeitos que os signos mundanos lhe remetem. E, assim, essa ação penetra num âmbito de passividade perante o que lhe acontece, recolhendo apenas o que acontece. São "aqueles que coincidem muito plenamente com a época, que em todos os aspectos a esta aderem perfeitamente, não são contemporâneos porque, exatamente por isso, não conseguem vê-la, não podem manter fixo o olhar sobre ela" (AGAMBEN, 2009, p.59). No entanto, o professor contemporâneo poderia tornar-se aquele que, observando uma sensibilidade aberta (KOHAN, 2007) aos signos, consegue e mantém o olhar fixo (rente aos acontecimentos da sala de aula): "sua época". Não como um hipnotizado, mas enquanto pesquisador de possíveis fendas que podem surgir na superfície da educação: "o escuro".

No escuro, brechas por onde podemos nos infiltrar em atividades podem manifestarse; também, podemos encontrar questões, moldes outros, onde desbravamos os signos do meio, onde o aprender acontece. Neste lugar, os encontros com os signos são possibilitados e aumentados em potência, oportunizando a ação do bom professor que "sabe ver essa obscuridade" na contemporaneidade. E, além disso, o professor esgotado pode tornar-se aquele que é "capaz de escrever mergulhando a pena nas trevas do presente" (AGAMBEN, 2009, p.63).

O escuro não é um conceito privativo, a simples ausência da luz, algo como uma
não-visão, mas o resultado da atividade das off-cells, um produto da nossa retina.
Isso significa, se voltamos agora à nossa tese sobre o escuro da contemporaneidade,
que perceber esse escuro não é uma forma de inércia ou de passividade, mas implica
uma atividade e uma habilidade particular que, no nosso caso, equivalem a
neutralizar as luzes que provêm da época para descobrir as suas trevas, o seu escuro
especial, que não é, no entanto, separável daquelas luzes. Pode dizer-se
contemporâneo apenas quem não se deixa cegar pelas luzes do século e consegue
entrever nessas a parte da sombra, a sua íntima obscuridade (AGAMBEN 2009,
p.63-64).

Ver as trevas, perceber o escuro, torna-se habilitar as off-cells docentes enquanto desbravador dos signos do aprender, tornando-se um bom professor. Não se deixando cegar pelas luzes deste século, ou do excesso e da velocidade dos signos mundanos, ele é capaz de ver a produtividade dos caminhos já existentes, cercados de brechas repletas de hieróglifos a serem interpretados. Entrevendo nas luzes a parte da sombra - as brechas, onde os encontros com os outros mundos dos signos são possíveis -, o professor percebe que esse escuro lhe concerne, sem cessar de interpretá-lo, ou seja, de aprender (AGAMBEN, 2009).

Percebemos um compromisso secreto entre o arcaico e o moderno: "a chave do moderno está escondida no imemorial e no pré-histórico" (AGAMBEN, 2009, p.70). 
Decisiva, torna-se aqui, também, a ideia de uma escola comum: não se trata de um consenso de alguns. O decifrador contemporâneo estabelece a forma de uma arqueologia que não regride a um passado remoto, mas a um não-vivido que possui alguma razão em sua extrema proximidade e a "atenção dirigida a esse não-vivido é a vida do contemporâneo. E, ser contemporâneo significa, neste sentido, voltar a um presente em que jamais estivemos" (AGAMBEN, 2009, p.70).

\begin{abstract}
Isso significa que o contemporâneo não é apenas aquele que, percebendo o escuro do presente, nele apreende a resoluta luz; é também aquele que, dividindo e interpolando o tempo, está à altura de transformá-lo e de colocá-lo em relação com os outros tempos, de nele ler de modo inédito a história, de "citá-la" segundo uma necessidade que não provém de maneira nenhuma do seu arbítrio, mas de uma exigência à qual ele não pode responder. É como se aquela invisível luz, que é o escuro do presente, projetasse a sua sombra sobre o passado, e este, tocado por esse facho de sombra, adquirisse a capacidade de responder às trevas do agora (AGAMBEN, 2009, p.72).
\end{abstract}

O professor contemporâneo como tal, pode levar o tempo que lhe resta na busca da verdade, até que uma luz violente os seus olhos- ao ponto deste não poder mais ficar com eles fechados -, perante o escuro que está à sua frente, até que algo force o pensamento a pôr-se em movimento. Porém, basta um instante e o professor tem tempo o bastante. Desde então, o que propomos consiste num velho olhar sobre o novo, ou num novo olhar sobre o velho, tanto que nem se percebe que estão lá, juntos, nos espaços e tempos imprevistos da escola. E, assim, o professor, pode tornar-se contemporâneo enquanto o efeito de um trabalho do pensamento, ou de preparação, com tudo o que ele tem ao seu redor (DELEUZE, 2007).

Mesmo em clichês, o professor contemporâneo pode encontrar possibilidades de fazer obra de arte na sala de aula e na escola. Pode estar aí, dir-se-ia, a potencialidade da sensibilidade aos signos do aprender em um espaço considerado. Todo o caminho, até aqui trilhado, precisou dos dados mundanos, conteúdos necessários ao aprendizado. Da mesma forma, o aprendizado não se vislumbraria sem eles enquanto efeito de um desdobramento coisas que ao acaso vão se chocando -, possibilidades de revelação do aprenderacontecimento (DELEUZE, 2011).

Mesmo que não possamos dizer “- - Aprendi!”. Pois, neste instante, há certo ágio, uma espécie de brecha entre o que foi proposto enquanto moda e o que se sabe: o aprender resvala através de um tempo kairós (quem sabe, mais adiante, extravase!). O presente une-se ao arcaico e, somente, quem percebe no mais moderno, e recente, os "índices e as assinaturas do arcaico" pode dele ser contemporâneo (AGAMBEN, 2009, p.69). Afinal, por meio dos signos mundanos, esgota-se o possível e possibilitam-se encontros em que a criação torna-se realmente “indizível” (BAMPI; TELICHEVESKY, 2012). 
Para nos encontrarmos a nós mesmos, precisamos contar com ações firmes, mesmo que se dissolvam em muitas imagens. Não são simples ações de fato, envolvidas em exercícios de pensamento, podem potencializar ações de direito. As ações implicam em um esforço pessoal que cada um realiza sobre si mesmo, onde os mundos dos signos entrechocam-se entre si para que um pouco de arte permaneça. Tornando-nos artistas de nós mesmos, podemos nos reinventar na vida e no pensamento.

A didática dos signos coexiste com as didáticas existentes. De início, ela funciona como uma espécie de foco que age mesmo antes de dar a conhecer uma verdade. Tem-se a impressão de chegar a ela, porém aprendemos que ela já está estava ali, o tempo todo, envolvida em todos os mundos dos signos. Os imperativos da linguagem dos signos marcam essa presença que, uma vez manifestada na nossa arte, reagirá sobre todos os tipos de aprendizados. Desde então, vislumbramos na alegria de uma revelação o correlato da ação enquanto tradução de signos.

\section{Referências}

AGAMBEN, G. A comunidade que vem. Tradução e notas de C. Oliveira. Belo Horizonte: Autêntica Editora, 2013.

AGAMBEN, G. O que é o contemporâneo? E outros ensaios. Tradução de V. N. Honesko. Chapecó: Argos, 2009.

BAMPI, L. et al Em meio ao PIBID e aos estágios de docência - da escrita na leitura. Zetetiké, Campinas, v. 21, n. 40, p. 120-125, jul./dez. 2013.

BAMPI, L. et al. Numa brincadeira de aprendiz de feiticeira... Surge algo. Revista Sul-Americana de Filosofia e Educação, Brasília, DF, n. 21, p. 170-184, nov. 2013/abr. 2014.

BAMPI, L.; TELICHEVESKY, M. A estudante e a professora fugitiva... Um encontro necessário. Childhood \& Philosophy, Rio de Janeiro, v. 8, n. 16, p. 459-476, jul./dez. 2012.

BENJAMIN, W. Experiência. In: Reflexões sobre a criança, o brinquedo e a educação. Tradução de M V. Mazzari. São Paulo: Editora 34, p. 21-26.

CALVINO, Í. Sob o sol-jaguar. Tradução de N. Moulin. São Paulo: Companhia das Letras, 1995.

CALVINO, Í. Todas as cosmicômicas. Tradução de I. B. e R.Barni. São Paulo: Companhia das Letras, 2007.

CAMARGO, G.; BAMPI, L. O que acontece no meio? Educação, Porto Alegre, v. 36, n. 3, p. 385392, set./dez. 2013.

CAMARGO, G.; BAMPI, L. Sobre o que pode a escola - Do professor cansado ao professor contemporâneo. In: VII CIFE - VII COLÓQUIO INTERNACIONAL DE FILOSOFIA DA EDUCAÇÃO, 2014, Anais. Rio de Janeiro, 2014. p.1-13. 
CORAZZA, S. M. Para pensar, pesquisar e artistar a educação: sem ensaio não há inspiração. In: Educação, São Paulo: Segmento, v. 6, 2007. p. 68-73.

DELEUZE, G. Espinosa: filosofia prática. Tradução de D. Lins e F. Pascal. São Paulo: Escuta, 2002.

DELEUZE, G. Francis Bacon: lógica da sensação. Tradução de R. Machado. Rio de Janeiro: Jorge Zahar Ed., 2007.

DELEUZE, G. Sobre o teatro: um manifesto de menos, o esgotado. Tradução de F. Saadi, O. de Abreu e R. Machado. Rio de Janeiro: Jorge Zahar, 2010.

DELEUZE, G. Lógica do sentido. Tradução de L. R. S Fortes. São Paulo: Perspectiva, 2011.

DELEUZE, G. P de professor. In: L’ ABÉCÉDAIRE de Gilles Deleuze. Entrevista com Gilles Deleuze. Editado: Brasil, Ministério de Educação, "TV Escola". Paris: Éditions Montparnasse, 1997. 1 videocassete, VHS, cor.

DELEUZE, G. Proust e os signos. Tradução de A. C. Piquet e R. Machado. 2. ed. Rio de Janeiro: Forense Universitária, 2003.

EUCLIDES. Os elementos. Tradução de I. Bicudo. São Paulo: Editora da UNESP, 2009.

GALLO, S. O problema e a experiência do pensamento: implicações para o ensino da filosofia. In: BORBA, S.; KOHAN, W. O. (Org.). Filosofia, aprendizagem e experiência. Belo Horizonte: Autêntica, 2008. p. 115-130.

KOHAN, W. O. A infância da educação: o conceito devir-criança. KOHAN, W. O. (Org.). Lugares da Infância: filosofia. Rio de Janeiro: DP\&A, 2004. p. 51-68.

KOHAN, W. O. O mestre inventor. Relatos de um viajante educador. Tradução de H. Freitas. 1.ed. Belo Horizonte: Autêntica Editora, 2013.

KOHAN, W. O. O que pode um professor?. In: Educação, São Paulo: Segmento, v.6, 2007. p. 48-57. RANCIÈRE, Jacques. O mestre ignorante. Tradução de L. Valle. 2. ed. Belo Horizonte: Autêntica, 2007.

SPINOZA, B. Ética. Tradução de T. T. da Silva. Belo Horizonte: Autêntica, 2007. 